\title{
Peer Scaffolding During EFL Reading Activities: A Sociocultural Perspective
}

\author{
Rattana Yawiloeng ${ }^{1}$ \\ ${ }^{1}$ School of Liberal Arts, University of Phayao, Phayao, Thailand \\ Correspondence: Rattana Yawiloeng, school of Liberal Arts, University of Phayao, Phayao, 56000, Thailand.
}

Received: October 26, 2021

Accepted: November 16, $2021 \quad$ Online Published: November 17, 2021

doi: $10.5539 /$ elt.v14n12p44

URL: https://doi.org/10.5539/elt.v14n12p44

\begin{abstract}
The purpose of this study was to identify the types of peer scaffolding used by Thai EFL students while completing reading activities. Pre-test, post-test and reading test procedures were implemented to measure the impact of peer scaffolding on students' reading comprehension. The peer scaffolding checklist was employed to identify the types of peer scaffolding the EFL students used in the reading classroom. This study found that the EFL students gained higher post-test mean scores after engaging in reading activities along with peer scaffolding strategies. The beginner and elementary EFL students mostly used procedural assistance, whereas the intermediate EFL students frequently used sharing and questing as peer scaffolding. These findings may provide sociocultural theoretical and pedagogical implications for EFL teachers when supporting peer scaffolding and assisting EFL students to develop reading comprehension.
\end{abstract}

Keywords: peer scaffolding, reading comprehension, EFL learners, sociocultural theory

\section{Introduction}

Reading is an important skill for learners since they have to read messages or texts in their daily life. Reading comprehension skills in English are particularly considered essential in most curriculum frameworks (Demissie, 2018 , p. 2). In an educational context, learners are expected to engage in reading activities as part of the learning process. This includes reading and interpreting texts to meet the learning goals (Grabe, 2009). Learners often have to read texts in both their first language (L1) and second language (L2). Learning to read English as a second language can enhance learners "to develop their English L2 abilities to the point at which advanced academic curricular goals can be achieved" (Grabe, 2009, p. 6). According to Kivi and colleagues (2021, p. 1031), L2 reading ability is already a requirement as English use becomes more prevalent, not only as a universal language but also as the language of science, technology, and advanced studies. In addition, Zarai and Alipour (2019) assert that because English is used as a medium for interaction all around the world, the ability to read in English is crucial as it is a skill that can assist learners to achieve their personal and occupational needs. Therefore, reading ability is important to help learners to achieve in both schools and the workplaces (Ardeshiri, 2019).

However, reading has been identified as a problematic issue for learners who use English as a foreign language (EFL) because they seldom read English outside of the classroom. In an EFL reading classroom, Rawengwan and Yawiloeng (2020) mentioned that Thai EFL learners tended to be passive learners and avoided to interact with their teacher or peers, consequently these EFL learners gained less reading comprehension. Regarding this pedagogical issue, problems with reading comprehension experienced by learners may be due to the inappropriate teaching of reading comprehension such as repeating reading without well-prepared teaching and learning activities, and lacking background knowledge of the topic (Muna, 2018). In addition, the ineffective use of reading strategies is assumed to be related to low reading comprehension among learners (Buli, Basizew \& Abdisa, 2017). Indeed, a widespread problem in the EFL context is that learners faced with obstacles to understanding English texts may delay the development of their reading comprehension (Karimi \& Jalilvand, 2014).

One way to overcome reading problems is through the use of scaffolding strategies. Scaffolding is as an effective teaching and learning strategy that can enhance learners to learn within a supportive learning environment. In a learning context, scaffolding is "a special kind of help that assists learners in moving toward new skills, concepts, or levels of understanding" (Gibbons, 2015, p. 16). In other words, scaffolding is used to provide learners with 
the necessary assistance to enable them "to accomplish tasks and development understandings that they would not be able to manage on their own" (Hammond \& Gibbons, 2005, p. 9). Thus, after gaining assistance from the teacher, the learner will be able to engage in the learning tasks independently (Gibbons, 2015).

Recent studies have paid increasing attention to methods of scaffolding reading comprehension skills (e.g. Ardeshiri, 2019; Buli et al., 2017; Salem, 2017; Smit, Grift, Bot, \& Jansen, 2017; Yusuk, 2018; Zarei \& Alipour, 2019). For example, Yusuk (2018) reported that scaffolding techniques can enhance Thai EFL students' reading comprehension by supporting them to draw on prior knowledge and create new information. Moreover, Zarei and Alipour (2019) examined the effects of scaffolding techniques (peer scaffolding, distributed scaffolding, and reciprocal scaffolding) on L2 reading comprehension. The researchers found that scaffolding techniques along with multimodal materials can facilitate the development of EFL learners' reading comprehension. Recently, Mezek and colleagues (2021) examined the effects of scaffolding on L2 academic reading by focusing on the task and feedback, they found that instructional scaffolding and teacher feedback were linked to the self-regulation behaviors of students.

To date, there has been less research evidence identifying the types of peer scaffolding that occur when EFL students engage in EFL reading activities with peers. Therefore, the aim of this study is to identify the types of peer scaffolding used by Thai EFL students and to investigate different types of peer scaffolding used by students with different levels of English prior knowledge.

\section{Literature Review}

\subsection{Scaffolding from a Sociocultural Perspective}

Definitions of Scaffolding in Sociocultural Contexts - From a sociocultural perspective of teaching and learning, scaffolding is described as the provision of particular forms of support to learners during interactions with parents, teachers, and other mentors to facilitate the development of new skills, concepts, or levels of understanding (Maybin et al., 1992). According to Wood, Bruner and Ross (1976), scaffolding "enables a child or novice to solve a problem, carry out a task or achieve a goal which would be beyond his unassisted efforts" ( $p$. 90). Educators and researchers further developed and refined the concept of scaffolding in educational contexts to view it as the "ability to capture the role of the "expert', or more knowledgeable other (typically the teacher)" (Hammond \& Gibbons, 2005, p. 10). In addition, Michell and Sharpe (2005) highlighted that "instructional scaffolding involves teachers in making conscious and subconscious decision about the support they think learners require to accomplish" (pp. 54-55). From a sociocultural learning perspective, scaffolding thus supports the premise that students gain opportunities to learn from others (e.g., experts and more knowledgeable people) and may, in turn, be used by teachers as a guideline to the provision of explicit teaching and learning strategies to assist learners.

Scaffolding in the Zone of Proximal Development (ZPD) - the ZPD refers to "What an individual can accomplish when working in collaboration with others versus what he or she could have accomplished without collaborations with others (Zuengler \& Miller, 2006, p. 39, as cited in Reza \& Mahmood, 2013, p. 68). When learning in a social context, scaffolding may occur within the ZPD; that is, the learner receives assistance from others to achieve at a level that he or she would not have been able to achieve alone (Walqui, 2006). In this sense, learners can acquire knowledge and skills by scaffolding sources available in the ZPD while being assisted by an expert, collaborating with peers, assisting a lower-level learner, or while working independently (Talley, 2014; Walqui, 2006). In the same way, Van de Pol, Mercer and Voman (2019) elaborated on the premise of Vygotsky's sociocultural theory that scaffolding is the support provided in the ZPD which is "the distance between what a learner can do independently and what he or she can do with the help of a more knowledgeable other" (p. 208). Thus, learning within the ZPD means learners received assistance from others and learn together with their peers, enabling them to subsequently learn independently without assistance. Teaching and learning in the ZPD are therefore important for teachers as they can provide learners with appropriate scaffolds to assist them to develop their L2 skills and knowledge in the classroom.

\subsection{Peer Scaffolding}

In the learning context, peer scaffolding is defined as "support provided by peers and guided by a scaffolding framework that allows students to meaningfully participate in and gain skill at a task that they could not complete unaided" (Belland, 2014, p. 2). In a learning context, peers scaffolding is a form of collaborative learning which has advantages in several ways, especially in terms of providing and receiving explanations that can help learners engage in deeper cognitive processing, such as clarifying thinking, reorganizing information, correcting misconceptions, and developing new understanding (Simeon, 2014 as cited in Chairinkam \& Yawiloeng, 2021, p. 228). During learning activities, learners have different abilities and can assist their peers to 
engage in higher-order thinking (Belland, 2014). Engaging in collaborative group work, peer scaffolding plays an important role in the learning context since it is "at times as useful as that provided by the teacher" (Gibbons, 2015 , p. 53). When learning together with peers, "sometimes students have differing abilities and can help each other move to higher-order thinking" (Belland, 2014, p. 9). To enhance effective peer scaffolding, the provision of peer tutoring opportunities and scaffolding guidance are necessary before engaging in the learning activities (Belland, 2014).

\subsection{Types of Peer Scaffolding}

Several peer scaffolding types are essential features that learners use to problem solve while engaging in learning activities. In problem-solving activities, peer scaffolding patterns are identified according to three dimensions: strategy dimension (maintaining direction, assigning role-talking); content (offering cue, opinion, explanation, and feedback); and affection (offering praise, inviting participation) (Park \& Jang, 2008). Peer scaffolding patterns including demonstration, procedural assistance, validation, and exchanging perspectives are also used to resolve learning problems in technology-enhanced classrooms (Kim \& Hannafin, 2011a). Moreover, Van de Pol et al. (2010) reviewed and synthesized scaffolding literature and distinguished six peer scaffolding methods to help complete learning activities: feedback, giving hints, instructing, explaining, modelling, and questioning.

\subsection{Previous Studies}

Previous studies have shown that several types of peer scaffolding may be used to facilitate learning. Shin et al. (2020) identified nine types of peer scaffolding during group activities: hinting, demonstrating, explaining, confirming, procedural assistance, providing feedback, posting, and clarifying. According to Shin and colleagues, high prior knowledge learners mostly used peer scaffolding types; namely, elaborating and posing. Regarding the mixed prior knowledge learners, the types of peer scaffolding frequently used were procedural assistance and feedback. In addition, the low prior knowledge learners preferred to use peer scaffolding to focus on procedural assistance. Shin et al. (2020) suggest instructional designers and teachers support students in their focus on quality peer scaffolding by asking critical questions or posing new ideas while engaging in group activities. Therefore, this current study is underpinned by the sociocultural theoretical framework for identifying peer scaffolding types as adapted from Shin et al. (2020) to scaffold vocabulary learning by students.

Recent studies have indicated the effects of peer scaffolding on EFL learners' reading comprehension. For example, Safadi and Rababah (2012) investigated the effect of scaffolding instruction on reading comprehension development by first-year secondary students. The researchers found that "scaffolded instruction enables students to improve their English language reading comprehension and develop proficient reading comprehension skills" (Safadi \& Rababah, 2012, p. 23). In addition, a study by Demissie (2018) investigated the effects of peer scaffolding on reading comprehension among first-year students at a university in Ethiopia. The study revealed that the first-year students (as both scaffold deliverers and scaffold receivers) showed greater pre-to-post-intervention improvement in reading comprehension and rated the intervention as socially valid.

A recent study by Kivi and colleagues (2021) investigated the effects of teacher and peer scaffolding on EFL learners' vocabulary learning and reading comprehension. During engaged in the peer-scaffolding group, the EFL students had the opportunity to be group leader in order to monitor and help their peers with their reading comprehension. The results of this study showed that the peer-scaffolding group gained reading comprehension scores higher than the teacher-scaffolding and control groups. Accordingly, the researchers recommended collaborative learning environments with peer scaffolding to support learners to correct themselves as well as to learn new and problem-solving skills. Importantly, the researchers suggested that a technology-enhanced setting should be considered when seeking to scaffold vocabulary learning for students. Recently, Lee (2021) conducted a study which focused on scaffolding university students' epistemic cognition during multimodal multiple-document reading. The results of this study revealed that multimodal multiple-document reading can served as strategic scaffolds for students to construct a coherent mental representation of the multiple documents consisting of diverse viewpoints (p. 9).

According to the literature review, however, there has been less research evidence generated on peer scaffolding types used by learners who have English prior knowledge based on their CEFL level. This study attempts to address this gap by investigating the types of peer scaffolding used by learners with different prior knowledge of English during EFL reading activities. 


\section{Method}

\subsection{Participants}

Thirty-four undergraduate students enrolled in an elective English course at a Thai university participated in this study. The sample included 25 males $(73.5 \%)$ and 9 females $(26.5 \%)$. Purposive sampling was conducted to recruit participants according to convenience and availability. The criterion for section was that the student had previously studied three compulsory courses of English.

Regarding participant demographics, they all spoke Thai as their L1 and English as a foreign language (EFL). Although the Thai EFL students had studied English in primary school and high school for 12 years, most had low English proficiency levels as shown in their pre-test scores (Table 1). Prior to data collection, all participants signed a consent form (initially provided to 34 students) and were informed that they could withdraw their participation in the study at any time. The participants engaged in reading activities in an English classroom over seven weeks.

\subsection{Instruments}

\subsubsection{Pre-Test Examining the Participants' English Prior Knowledge (CEFR Level)}

The Common European Framework of Reference (CEFR) has three board bands and six levels; that is, level A or basic user (A1 Breakthrough and A2 Waystage), level B or independent user (B1 Threshold and B2 Vantage), and level $\mathrm{C}$ or proficient user (C1 Effective operational proficiency and C2 Master) (Council of Europe, 2004). As Thai Ministry of Education (MOE) has announced the CEFR as a guideline for English classroom learning and teaching management in Thailand (English Language Institute, 2016 as cited in Chartrakul \& Damnet, 2021, p. 82); therefore, the CEFR test was used to identify the EFL participants' English prior knowledge level.

The pre-test was used to identify the Thai EFL students' prior knowledge of English and to examine whether EFL students with different levels of prior knowledge used different peer scaffolding types. The pre-test and post-test instruments were identical, adopted from an English Placement test used for EFL students at a university in Poland where English is also used as a foreign language. In this present study, the tests were conducted to assess the Thai EFL students' English prior knowledge using scores comparable to the CEFR Level; that is, ranges from $0-19$ points (A1), 20-35 points (A2), and 36-50 points (B1). The test consisted of 50 multiple-choice questions to assess vocabulary and grammar. Test validity was assessed by three experts in the field of English language teaching. Results from the pre-test on English prior knowledge revealed 24 beginner level students (A1), 8 elementary level students (A2), and 2 intermediate level students (B1) as shown in Table 1.

Table 1. Pre-test to differentiate the EFL students' English prior knowledge level

\begin{tabular}{lllll}
\hline The participants' English prior knowledge level & Number & Percent (\%) & \multicolumn{2}{c}{ Pre-test scores (50) } \\
& & & Min. & Max \\
\hline Beginner level (A1) & 24 & 70.59 & 7 & 19 \\
Elementary level (A2) & 8 & 23.52 & 20 & 30 \\
Intermediate level (B1) & 2 & 5.89 & 38 & 45 \\
Total & 34 & 100 & & \\
\hline
\end{tabular}

3.2.2 Reading Test

The reading tests were adopted from an intermediate B1 reading contributed by the British Council, the United Kingdom's international organization for cultural relations and educational opportunities. The reading tests (both pre-test and post-test) were used to examine the EFL students' reading comprehension before and after the provision of instructional scaffolding and peer scaffolding during the reading activities. Five reading texts from the British Council website were selected for the reading activities. The B1 readings were multimodal texts presented together with photos, images, and authentic forms of reading texts that students can access in their daily lives. In terms of content and structure, the reading texts included a job advertisement, email exchange, noticeboard announcement, friendship quiz, and online blog. Three experts were asked to check the validity and reliability of the multimodal reading tests prior to their use in the reading activities. In terms of the structure of the reading tests, there were 20 multiple choice questions. Each reading comprehension test comprised items to help evaluate vocabulary knowledge, ability to recognize main ideas, and inferring. 
To collect the research data in each session, the pre-test was conducted before the EFL students participated in the reading activities. After the students engaged in the reading activities with instructional scaffolding and peer scaffolding, the post-test (with the same format as the pre-test) was implemented. The students were allocated 40 minutes to answer 20 questions in each test.

\subsubsection{Peer Scaffolding Checklist}

The peer scaffolding checklist was utilized to evaluate the types of peer scaffolding used by the EFL students during the EFL reading activities. The checklist evaluated 10 types of peer scaffolding: hinting, demonstrating, explaining, confirming, procedural assistance, providing feedback, posing, clarifying, sharing, and questioning. Five-point Likert scale questions were used in this checklist with the rate meanings of each statement in the checklist described according to the following criteria: $4.51-5.00$ (frequently use), $3.51-4.50$ (almost every time), $2.51-3.50$ (occasionally), $1.51-2.50$ (almost never), and 1.00-1.50 (never use). To avoid misunderstanding the peer scaffolding checklist in English, the researcher translated the peer scaffolding types into the participants' L1 (Thai). The questionnaire was validated by three experts in the field of EFL teaching.

\subsection{Data Collection}

The Thai EFL students in this study participated in reading activities that included the use of instructional scaffolding and peer scaffolding strategies. After signing the consent form, the 50-item pre-test was distributed to the EFL students to examine their English prior knowledge level. Then, the EFL students were divided into three groups: beginner level, elementary level, and intermediate level according to the pre-test results.

During the five-week period, teacher scaffolding strategies were offered in order to enhance the Thai EFL students' peer scaffolding competences while aiming to assist their peers to comprehend the reading tasks. Teacher scaffolding strategies: namely, feedback, hints, instructing, explaining, modelling and questioning were adapted from Van de Pol et al. (2010) and used to assist the learners to understand and develop reading strategies during the pre-reading, while reading, and post-reading stages. Before the pre-reading stage, the pre-test was administered to the participants to examine their reading comprehension prior to receiving peer scaffolding.

During the final reading activity, the peer scaffolding checklist was distributed to participants to investigate the peer scaffolding types they used while engaging in the reading activities with the teacher and their peers. Lastly, the post-test was administered to assess the students' English knowledge again in order to examine their learning development after receiving peer scaffolding.

\subsection{Data Analysis}

Data obtained from the pre-test and post-test instruments, along with the checklist, were analyzed quantitatively. SPSS software was used to analyze the mean paired and independent t-test to examine the Thai EFL students' reading comprehension after engaging in the reading activities and the use of peer scaffolding strategies. Descriptive statistical analyses were conducted using the SPSS software to identify the peer scaffolding types and frequencies.

\section{Results}

\subsection{Analysis of Pre-Test and Post-Test}

Table 2 presents descriptive statistics of the pre-test and post-test results regarding the Thai EFL learners' prior knowledge of English before and after they engaged in the reading activities using multimodal texts, teacher scaffolding, and peer scaffolding strategies. The 50 -item pre-test was administered to 34 students in the first week before they participated in the reading activities. The post-test was administered to the students again on the sixth week after they engaged in five weeks of reading activities.

Table 2. Pre-test and post-test results of the students' knowledge of English

\begin{tabular}{lllllll}
\hline Test & Number & Mean & Std. Deviation & Std. Error Mean & Min. (50) & Max. (50) \\
\hline Pre-test & 34 & 17.971 & 7.9066 & 1.3560 & 7 & 38 \\
Post-test & 34 & 23.294 & 8.2848 & 1.4208 & 13 & 50 \\
\hline
\end{tabular}

The results in Table 2 show that the Thai EFL students' post-test scores were higher than their pre-test scores. Statistical analysis shows the mean of the pre-test scores was 17.971 ( $\mathrm{SD}=7.9066)$. After engaging in the English learning activities - which included teacher scaffolding and peer scaffolding - over the five-week period, the mean of the post-test scores had increased to 23.294 ( $\mathrm{SD}=8.2848$ ). When considering the students' minimum and maximum scores, it was found that the minimum and maximum scores of the pre-test and post-test 
had risen from 7 to 13 and from 38 to 50, respectively. This indicates that peer scaffolding can enhance EFL students' prior knowledge of English by participating in English learning activities with peers.

\subsection{Results from the Pre- and Post-Test for Reading Comprehension}

Table 3 shows the results of the pre-test and post-test related to the EFL students' reading comprehension. The tests were administered before and after the participants received peer scaffolding within the reading activity period. Before the reading activities, the EFL students were asked to complete the pre-test without having received any peer scaffolding. After receiving instructional scaffolding and peer scaffolding during the reading activities, the students were asked to complete the post-test.

Table 3. Results of the reading comprehension pre-test and post-test

\begin{tabular}{lllll}
\hline Sessions & Tests & $\mathrm{N}$ & Mean $\overline{\mathrm{x}}$ & Std. Deviation \\
\hline Reading Session 1 & Pre-reading & 34 & 11.676 & 5.1799 \\
(Job Advertisements) & Post-reading & 34 & 18.515 & 1.7166 \\
Reading Session 2 & Pre-reading & 34 & 13.250 & 4.4827 \\
(Email Exchange) & Post-reading & 34 & 18.985 & 1.7688 \\
Reading Session 3 & Pre-reading & 34 & 12.471 & 3.8631 \\
(Notice Board) & Post-reading & 34 & 16.706 & 3.3981 \\
Reading Session 4 & Pre-reading & 34 & 14.765 & 4.2573 \\
(Friendship Quiz) & Post-reading & 34 & 18.588 & 1.7472 \\
Reading Session 5 & Pre-reading & 34 & 12.103 & 2.9408 \\
(Tips for Students) & Post-reading & 34 & 18.191 & 2.2463
\end{tabular}

As seen in Table 3, results for the post-tests across the five reading sessions were higher than for the pre-tests. After receiving peer scaffolding during the reading activities, the EFL students achieved the highest post-test scores $(\overline{\mathrm{x}}=18.985, \mathrm{SD}=1.7688)$ in reading session 2, (Email Exchange) followed by reading session $1(\overline{\mathrm{x}}=$ $18.515, \mathrm{SD}=1.7166)$ (Job Advertisements). The lowest post-test score $(\overline{\mathrm{x}}=16.706, \mathrm{SD}=3.3981)$ achieved by the EFL students was in reading session 3 (Notice Board).

\subsection{Peer Scaffolding Types Used while Engaging in EFL Reading Activities}

Table 4 shows the types of peer scaffolding used by the EFL students. After engaging in reading activities five times over a five-week period, the EFL students were asked to complete the peer scaffolding checklist in their L1 (Thai) to indicate the types of peer scaffolding they used while participating in the reading tasks with peers. The EFL students spent approximately 20 minutes to complete the checklist after the final reading activity. The peer scaffolding types were identified based on the EFL students' distinct levels of prior knowledge (see Table 4): 
Table 4. Peer scaffolding types used by the EFL students during the reading activities

\begin{tabular}{|c|c|c|c|c|}
\hline Statements & Peer scaffolding types & Mean & Std. Deviation & Frequency of Use \\
\hline $\begin{array}{l}\text { 1. I provide a hint to my peer to enhance their reading } \\
\text { comprehension. }\end{array}$ & Hinting & 3.29 & .938 & $\begin{array}{l}\text { Almost } \\
\text { every time }\end{array}$ \\
\hline $\begin{array}{l}\text { 2. I demonstrate sample reading strategies to my peer to } \\
\text { enhance their reading comprehension. }\end{array}$ & Demonstrating & 3.38 & .954 & $\begin{array}{l}\text { Almost } \\
\text { every time }\end{array}$ \\
\hline $\begin{array}{l}\text { 3. I explain things in more detail to my peer to assist their } \\
\text { reading comprehension. }\end{array}$ & Explaining & 3.32 & .912 & $\begin{array}{l}\text { Almost } \\
\text { every time }\end{array}$ \\
\hline 4. I confirm that my peer's answer is understood. & Confirming & 3.76 & .781 & Frequently use \\
\hline 5. I ask for help and suggestions from my peer. & Procedural assistance & 3.76 & 1.017 & Frequently use \\
\hline $\begin{array}{l}\text { 6. I provide feedback to my peer to develop their reading } \\
\text { comprehension. }\end{array}$ & Providing feedback & 3.47 & .748 & $\begin{array}{l}\text { Almost } \\
\text { every time }\end{array}$ \\
\hline $\begin{array}{l}\text { 7. I pose ideas to my peer to develop their reading } \\
\text { comprehension. }\end{array}$ & Posing & 3.41 & .957 & $\begin{array}{l}\text { Almost } \\
\text { every time }\end{array}$ \\
\hline $\begin{array}{l}\text { 8. I clarify my ideas and examples of reading techniques } \\
\text { to my peer to develop their reading comprehension. }\end{array}$ & Clarifying & 3.32 & .727 & $\begin{array}{l}\text { Almost } \\
\text { every time }\end{array}$ \\
\hline $\begin{array}{l}\text { 9. I share my experiences and mistakes with my peer to } \\
\text { help us to learn together. }\end{array}$ & Sharing & 3.76 & .955 & Frequently use \\
\hline 10. I ask my peer questions during the reading activities. & Questioning & 3.71 & 1.115 & Frequently use \\
\hline
\end{tabular}

Table 4 shows the types of peer scaffolding identified by the EFL students while engaging in the English reading activities with their peers. Analysis of the peer scaffolding checklist revealed the Thai EFL students frequently used Procedural Assistance $(\overline{\mathrm{x}}=3.76, \mathrm{SD}=1.017)$, Sharing $(\overline{\mathrm{x}}=3.76, \mathrm{SD}=.955)$, and Confirming $(\overline{\mathrm{x}}=3.76, \mathrm{SD}$ $=.781$ ) during the reading activities. As outlined in Table 4, the Thai EFL students mostly used Procedural Assistance as peer scaffolding to ask for help from their peers when they attempted to solve L2 reading problems. In addition, the EFL students utilized Sharing to disclose experiences and mistakes and confirming to verify their peers' answers, respectively. Notably, analysis of the peer scaffolding checklist responses revealed the Thai EFL students used Hinting $(\overline{\mathrm{x}}=3.29, \mathrm{SD}=.938)$ almost every time. Hinting was used least frequently among other peer scaffolding types.

\subsection{Peer Scaffolding Types Used by EFL Students with Different CEFR Levels}

Table 5 shows the peer scaffolding types used by the EFL students who had English prior knowledge at the beginner level (A1), the elementary level (A2), and the intermediate level (B1). These students included 18 males and 6 females who sat the English Placement Test to assess their English prior knowledge level prior to engaging in the reading activities. The students learnt to read English texts along with instructional scaffolding and peer scaffolding in the EFL reading classroom.

Table 5. Peer scaffolding types used by the EFL students at different prior knowledge levels

\begin{tabular}{lllllll}
\hline Peer scaffolding types & \multicolumn{3}{l}{$\begin{array}{l}\text { Beginner level } \\
(\mathrm{A} 1 / \mathrm{n}=24)\end{array}$} & \multicolumn{2}{l}{$\begin{array}{l}\text { Elementary level } \\
(\mathrm{A} 2 / \mathrm{n}=8)\end{array}$} & \multicolumn{2}{l}{$\begin{array}{l}\text { Intermediate level } \\
(\mathrm{B} 1 / \mathrm{n}=2)\end{array}$} \\
& $\mathrm{M}$ & $\mathrm{SD}$ & $\mathrm{M}$ & $\mathrm{SD}$ & $\mathrm{M}$ & $\mathrm{SD}$ \\
\hline 1. Hinting & 3.12 & .900 & 4.00 & 1.069 & 4.00 & .000 \\
2. Demonstrating & 3.04 & .999 & 3.75 & .886 & 4.00 & .000 \\
3. Explaining & 3.13 & .850 & 3.63 & 1.188 & 3.50 & .707 \\
4. Confirming & 3.42 & .776 & 3.88 & .835 & 4.00 & 1.414 \\
5. Procedural Assistance & 4.08 & .654 & 4.25 & .707 & 3.00 & 1.414 \\
6. Providing Feedback & 3.25 & 1.032 & 3.63 & .744 & 4.00 & 1.414 \\
7. Posing & 3.17 & .917 & 3.50 & .926 & 4.00 & .000 \\
8. Clarifying & 3.33 & .761 & 3.50 & .926 & 3.50 & .707 \\
9. Sharing & 3.54 & .977 & 4.00 & 1.069 & 5.00 & .000 \\
10. Questioning & 3.71 & .908 & 3.63 & 1.598 & 5.00 & .000 \\
\hline
\end{tabular}


Table 5 indicates the Thai EFL students with different English prior knowledge levels used different peer scaffolding strategies to help peers while completing the reading activities. When comparing the use of peer scaffolding among the three groups of students, those students who had English prior knowledge at the intermediate level (B1) used several types of peer scaffolding in higher frequencies than those who were at the beginner level (A1) and the elementary level (A2).

To clarify, beginner level learners (A1) used Procedural Assistance the most times during the reading activities as shown by the highest mean score $(\overline{\mathrm{x}}=4.08, \mathrm{SD}=654)$. Conversely, these learners used Demonstrating as a peer scaffolding strategy only occasionally, as shown the lowest mean score $(\overline{\mathrm{x}}=3.04, \mathrm{SD}=.999)$. Similar to the beginner level learners, the elementary level learners (A2) tended to use Procedural Assistance the most while participating in the reading activities, reflected in the highest mean score $(\overline{\mathrm{x}}=4.25, \mathrm{SD}=.707)$. Posing and Clarifying as peer scaffolding strategies were used the least frequently by this cohort as shown in the lowest mean score $(\overline{\mathrm{x}}=3.50, \mathrm{SD}=.926)$. For the intermediate level learners $(B 1)$, Sharing and Questioning were the most frequently used peer scaffolding strategies, achieving the highest mean score $(\overline{\mathrm{x}}=5.00, \mathrm{SD}=.000)$. In contrast to the beginner level and elementary level learners, the intermediate level learners used Procedural Assistance as a peer scaffolding strategy only occasionally while completing the reading activities as shown in the lowest mean score $(\overline{\mathrm{x}}=3.00, \mathrm{SD}=1.414)$.

\section{Discussion}

\subsection{Peer Scaffolding and Reading Comprehension}

The present study aimed to investigate the effects of peer scaffolding on reading comprehension of Thai EFL. The findings suggest that the EFL learners gained better reading comprehension after they used and received peer scaffolding during the reading activities. This confirms previous findings reported by Safadi and Rababah (2012) that "scaffolded instruction enables students to improve their English language reading comprehension and develop proficient reading comprehension skills, such as inferential and referential levels, vocabulary, main idea, and critical thinking" (p. 23). Moreover, the findings of this study are consistent with the assertion by Zarei and Alipour (2019) that scaffolding is an effective technique for developing reading comprehension and, consequently, the confidence and motivation of EFL students.

\subsection{The Types of Peer Scaffolding in the EFL Reading Activities}

Regarding the types of peer scaffolding, this study found that Procedural Assistance was the most-frequently used strategy by EFL learners while engaging in reading activities with peers. This result supports the finding in Shin and colleagues' study (2020) that Procedural Assistance was the mostly used peer scaffolding strategy by nine students while participating in inquiry-based learning (BL) group activities. The researchers identified Procedural Assistance as peer scaffolding when "students asked for process-related help, direction, suggestions, or possible courses of action" (Shin et al., 2020, p. 2332). The results of the present study also confirm Lange, Costley, and Han's (2016) assertion that receiving procedural guideline scaffolding involves "breaking tasks down into individual and sequential steps so students get to a point where they can take over the task without any further support from the instructor" (p. 262).

The results of this study also revealed that Hinting was the least-frequently used peer scaffolding type by the EFL students. Similar results were reported by Kim and Hannafin (2011b) in their study of students participating in inquiry-based learning group activities. This may be because the Thai EFL students had English prior knowledge at the beginner level. Consequently, it would likely be difficult for them to provide Hinting scaffolding to help their peers to develop their reading comprehension. As Shin and colleagues (2020) stated, "hinting is the provision of clues or suggestions given by peers in an indirect or subtle manner to help another peer to proceed in a task related to their inquiry activities" (p. 2332). Therefore, the results of this present study confirm Shin et al.'s (2020) claim that "the students' levels of prior knowledge may have had an impact on the quality of their peer scaffolding" (p. 2345).

Importantly, the findings of this study revealed that several types of peer scaffolding were used by EFL learners according to their level of English prior knowledge. Specifically, the beginner level (A1) and elementary level (A2) groups often used Procedural Assistance to ask for help and suggestions from their peers. In line with previous studies, Kim and Hannafin (2011a, 2011b) stated that Procedural Assistance was used to discover the answers from peers through a process of negotiation. In addition, Shin et al. (2020) viewed Procedural Assistance as a type of peer scaffolding that "entails monitoring each other's progress/quality and performing check-ups on each other' learning processes" (p. 2332). In contrast to the beginner level and elementary level groups, the intermediate level (B1) group often used Sharing and Questioning as scaffolding strategies while engaging in reading activities with peers. This consistent with what has been found in a study of Rawengwan and 
Yawiloeng (2020) that Thai EFL learners used Questioning strategy in order to understand the main idea and to gain reading comprehension. This finding also supports the premise associated with scaffolding that the more knowledgeable person shares her/his understanding of the learning goals to complete the task (Puntambekar \& Hubscher, 2010; Belland et al., 2013). In addition, Van de Pol (2010) mentioned that Questioning is focused on students' cognitive activities. In accordance with other scholars, Kim and Hannafin (2011a) also stated that Questioning and Sharing experiences involve problem identification and engagement that supports the learners to identify authentic problems and generating learning goals.

\section{Conclusion}

Evidence from this study suggests that peer scaffolding plays a key role in enhancing reading comprehension in EFL contexts. From a sociocultural perspective, it is apparent that in relation to reading comprehension, "scaffolding refers to any support given to a learner which helps him/her to obtain meaning and get the overall understanding of the content of a text" (Aliyu \& Yakubu, 2019, p. 85).

Moreover, when viewed from a sociocultural perspective, the finding of this study implies that "learners acquire knowledge from interactions with peers and experts who are more knowledgeable" (Aliyu \& Yakubu, 2019, p. 87). The evidence also implies that peer scaffolding should be endorsed in EFL reading classrooms to help learners to acquire reading comprehension. In addition, learner background knowledge should be considered a crucial factor to facilitate reading comprehension since it is "fundamental in reading comprehension in a foreign language context" (Troudi \& Zayani, 2020, p. 10). In addition, to assist EFL learners to gain reading comprehension as well as L2 learning, educational material developers may develop effective multimedia and consider appropriate multimedia modes for EFL classrooms (Yawiloeng, 2020). Therefore, future studies should focus on enhancing reading comprehension through the use of multimodal texts along with peer scaffolding techniques within a multimodal learning environment.

\section{Acknowledgements}

This research project was funded by Unit of Exellence (UoE), University of Phayao, Thailand.

\section{References}

Aliyu, M. M., \& Yakubu, H. (2019). Implications of the sociocultural theory on students' reading comprehension. Bulletin of Advanced English Studies, 3(2), 84-91. https://doi.org/10.31559/baes2019.3.2.3

Ardeshiri, M. (2019). Technology-based intervention in L2 reading comprehension: Towards digital scaffolding. Dissertation. University of Toronto, Canada.

Belland, B. R., Kim, C., \& Hannafin, M. J. (2013). A framework for designing scaffolds that improve motivation and cognition. Educational Psychologist, 48(4), 243-270. https://doi.org/10.1080/00461520.2013.838920

Belland, B. R. (2014). Scaffolding: Definition, Current Debates, and Future Directions. In Spector, J., Merrill, M., Elen, J. \& Bishop, M. (Eds.), Handbook of Research on Educational Communications and Technology. Springer, New York, NY. https://doi.org/10.1007/978-1-4614-3185-5_39

Buli, Z., Basizew, S., \& Abdisa, K. (2017). Effects of teachers' scaffolding on students' reading comprehension: Sire Secondary School grade nine students in focus. International Journal of Graduate Research and Review, 3(4), 89-95.

Chairinkam, J., \& Yawiloeng, R. (2021). Peer scaffolding behaviors in English as a foreign language writing classroom. Asian Journal of Education and Training, 7(4), 226-234. https://doi.org/10.20448/journal.522.2021.74.226.234

Charttrakul, K., \& Damnet, A. (2021). Role of the CEFR and English teaching in Thailand: A case study of Rajabhat universities. Advances in Language and Literacy Studies, 12(2), 82-89. https://doi.org/10.7575/aiac.alls.v.12n.2.p.82

Demissie, D. W. (2018). Peer scaffolding and its effects on reading comprehension: Evidence from Ethiopia. International Journal of Research in Social Sciences and Humanities, 8(3), 1-16.

Gibbons, P. (2015). Scaffolding language scaffolding learning: Teaching English language learners in the mainstream classroom. (2nd ed.). Portsmouth, USA.

Grabe, W. (2009). Reading in a second language: Moving from theory to practice. New York: Cambridge University Press. https://doi.org/10.1017/CBO9781139150484

Hammond, J., \& Gibbons, P. (2005). Putting scaffolding to work: The contribution of scaffolding in articulating ESL education. Prospect, 20(1), 6-30. 
Karimi, L., \& Jalivand, M. (2014). The effect of peer and teacher scaffolding on the reading comprehension of EFL learners in asymmetrical and symmetrical groups. The Journal of Teaching Language Skills (JTLS), 5(4), 1-77.

Kim, M. C., \& Hannafin, M. J. (2011a). Scaffolding problem solving in technology-enhanced learning environments (TELs): Bridging research and theory with practice. Computers \& Education, 56(2011), 403-417. https://doi.org/10.1016/j.compedu.2010.08.024

Kim, M. C., \& Hannafin, M. J. (2011b). Scaffolding $6^{\text {th }}$ graders' problem solving in technology-enhanced science classrooms: A qualitative case study. Instructional Science, 39, 255-282. https://doi.org/10.1007/s11251-010-9127-4

Kivi, P. J., Namaziandost, E., Alamdari, E. F., Saenko, N. R., Inga-Arias, M., Fuster-Guillen, D., Sirirakpanich, D., \& Nasirin, C. (2021). The comparative effects of teacher versus peer-scaffolding on EFL learners' incidental vocabulary learning and readingcomprehension: A socio-cultural perspective. Journal of Psycholinguistic Research, 50, 1031-1047. https://doi.org/10.1007/s10936-021-09800-4

Lang, C., Costley, J., \& Han, S. L. (2016). Informal cooperative learning in small groups: The effect of scaffolding on participation. Issues in Educational Research, 26(2), 260-278.

Lee, Y. (2021). Scaffolding university students' epistemic cognition during multimodal multiple-document reading: The effects of epistemic prompting and the automated reflection report. The Internet and Higher Education, 49, 100777. https://doi.org/10.1016/j.iheduc.2020.100777

Maybin, J., Mercer, N., \& Stierer, B. (1992). 'Scaffolding': learning in the classroom. In Norman, Kate (Ed.), Thinking Voices: The work of the National Oracy Project (pp. 186-195). London: Hodder \& Stoughton.

Mezek, S., Berggren, J., Maccrath, L., \& Negretti, R. (2021). Scaffolding L2 academic reading and self-regulation through task and feedback. TESOL Quarterly, 1-26. https://doi.org/10.1002/tesq.3018

Mitchell, M., \& Sharpe, T. (2005). Collective instructional scaffolding in English as a second language classrooms. Prospect, 20(1), 31-58.

Muna, N. (2018). The effectiveness of scaffolding to students' reading comprehension on narrative text. The State Institute Islamic University, Indonesia.

Park, S. I., \& Jang, S. Y. (2008). Analysis of peer scaffolding patterns in four phases of problem-solving in web-based instruction. The SNU Journal of Education Research, 17, 1-31.

Puntambekar, S., \& Hubscher, R. (2010). Tools for scaffolding students in a complex learning environment: What have we gained and what have we missed? Educational Psychologist, 40(1), 1-12. https://doi.org/10.1207/s15326985ep4001_1

Rawengwan, W., \& Yawiloeng, R. (2020). Reciprocal teaching method for enhancing Thai EFL learners' reading comprehension ability. Sripatum Review of Humanities and Social Sciences, 20(1), 105-123.

Reza, G. S., \& Mahmood, D. (2013). Sociocultural theory and reading comprehension: The scaffolding of readers in an EFL context. International Journal of Research Studies in Language Learning, 2(3), 67-80. https://doi.org/10.5861/ijrsll.2012.183

Safadi, E., \& Rababah, G. (2012). The effects of scaffolding instruction on reading comprehension skills. International Journal of Language Studies, 6(2), 1-38.

Salem, A. A. M. S. (2017). Scaffolding reading comprehension skills. English Language Teaching, 10(1), 97-111. https://doi.org/10.5539/elt.v10n1p97

Shin, S., Brush, T. A., \& Glazewski, K. D. (2020). Patterns of peer scaffolding in technology-enhanced inquiry classrooms: Application of social network analysis. Educational Technology Research and Development, 68, 2321-2350. https://doi.org/10.1007/s11423-020-09779-0

Smit, N., Van de Grift, W., Bot, K. D., \& Jansen, E. (2017). A classroom observation tool for scaffolding reading comprehension. System, 65(2017), 117-129. https://doi.org/10.1016/j.system.2016.12.014

Talley, P. C. (2014). Students' Responses to Scaffolded Learning in the Asian University ESL Classroom. International Journal of Business and Social Science, 5, 235-244.

Troudi, S., \& Zayani, E. M. (2020). Scaffolding EFL teachers' black box: Towards a theoretical framework of EFL teachers' reading knowledge. International Journal of Research and Innovation in Social Sciences, 4(7), 715 . 
Van de Pol, J., Mercer, N., \& Volman, M. (2019). Scaffolding Student Understanding in Small-Group Work: Students' Uptake of Teacher Support in Subsequent Small-Group Interaction. Journal of the Learning Sciences, 28(2), 206-239. https://doi.org/10.1080/10508406.2018.1522258

Van de Pol, J., Volman, M., \& Beishuizen, J. (2010). Scaffolding in teacher-student interaction: A decade research. Educ Phychol Rev, 22, 271-296. https://doi.org/10.1007/s10648-010-9127-6

Walqui, A. (2006). Scaffolding Instruction for English Language Learners: A Conceptual Framework. International Journal of Bilingual Education and Bilingualism, 9(2), 159-180. https://doi.org/10.1080/13670050608668639

Wood, D. J., Bruner, J. S., \& Ross, G. (1976). The Role of Tutoring in Problem Solving. Journal of Child Psychiatry and Psychology, 17, 89-100. https://doi.org/10.1111/j.1469-7610.1976.tb00381.x

Yawiloeng, R. (2020). Second Language Vocabulary Learning from Viewing Video in an EFL Classroom. English Language Teaching, 13(7). https://doi.org/10.5539/elt.v13n7p76

Yusuk, S. (2018). Effects of the zone of proximal development based scaffolding techniques on reading comprehension of Thai university students. Journal of Thai Interdisciplinary Research, 13(4), 1-6.

Zarai, A. A., \& Alipour, H. (2019). Shadowing and scaffolding techniques affecting L2 Reading comprehension. Applied Research on English Language, 9(1), 665-686. https://doi.org/10.22108/are.2019.117030.1462

\section{Copyrights}

Copyright for this article is retained by the author(s), with first publication rights granted to the journal.

This is an open-access article distributed under the terms and conditions of the Creative Commons Attribution license (http://creativecommons.org/licenses/by/4.0/). 